\title{
Association between passive smoking and Mycobacterium tuberculosis infection in children with household TB contact
}

\author{
Novaily Zuliartha, Ridwan M. Daulay, Melda Deliana, Wisman Dalimunthe, \\ Rini Savitri Daulay
}

\begin{abstract}
Background Tuberculosis (TB) and cigarette consumption are relatively high in Indonesia. Passive smoking may increase the risk of infection and disease in adults and children exposed to TB. An association between passive smoking and Mycobacterium tuberculosis infection in children has not been well documented. Objective To assess for an association between passive smoking and M. tuberculosis infection in children who had household contact with a TB patient.

Methods This cross-sectional study was conducted in February and March 2011. Children aged 5 to 18 years who had household contact with a TB patient underwent tuberculin testing for $\mathrm{M}$. tuberculosis infection. Subjects were divided into two groups: those exposed to passive smoke and those not exposed to passive smoke. Chi-square test was used to assess for an association between passive smoking and M. tuberculosis infection.

Results There were 140 children enrolled in this study, with 70 exposed to passive smoke and 70 not exposed to passive smoke. Prevalence of M. tuberculosis infection was significantly higher in the passive smoking group than in those not exposed to passive smoke $[81.4 \%$ and $52.9 \%$, respectively, $(\mathrm{P}=0.0001)]$. In the passive smoking group there were significant associations between nutritional state, paternal and maternal education, and $M$. tuberculosis infection. But no associations were found between $M$. tuberculosis infection and familial income or BCG vaccination.

Conclusion Among children who had household contact with a TB patient, they who exposed to passive smoke are more likely to have M. tuberculosis infection compared to they who not exposed to passive smoke. [Paediatr Indones. 2015;55:29-34.].
\end{abstract}

Keywords: passive smoking, M. tuberculosis infection, children
Tuberculosis (TB) remains a worldwide, public health problem. An estimated one-third of the world's population is infected with Mycobacterium tuberculosis. ${ }^{1}$ In developing countries, TB in children under 15 years of age accounts for $15 \%$ of all TB cases, however, in developed countries, the prevalence decreases to below 5 to $7 \% .^{2}$

Tuberculosis in children requires a different approach than adult $\mathrm{TB},{ }^{2}$ with regards to diagnosis, treatment, prevention, and human immunodeficiency virus (HIV) status. Diagnosing pediatric TB is difficult, largely due to the non-specific clinical manifestations of the disease in children. ${ }^{3,4}$ Nonetheless, the tuberculin test is often used to detect M. tuberculosis infection in children. ${ }^{4,5}$

Passive smoking is a widespread and avoidable risk factor for respiratory symptoms in both children

This study was presented at the Pertemuan Ilmiah Tahunan (PIT) IKA V Bandung, October 15-17, 2012.

From the Department of Child Health, University of Sumatera Utara Medical School/H. Adam Malik General Hospital, Medan.

Reprint requests to: Dr. Novaily Zuliartha, Department of Child Health, University of Sumatera Utara Medical School, H. Adam Malik Hospital, Jl. Bunga Lau No.17, Medan 20136. Tel. +62-61 8361721 - 8365663 Fax.+62-618361721. E-mail: znovaily@yahoo.com. 
and adults. ${ }^{6}$ Passive smoking is associated with M. tuberculosis infection in children living in a household with a tuberculosis patient. ${ }^{7-9}$ Tuberculosis and smoking are both significant public health problems. An association between passive smoking and M.tuberculosis infection in children is not welldocumented. ${ }^{7}$ The objective of this study was to examine the potential association between passive smoking and M. tuberculosis infection in children living in households with a tuberculosis patient.

\section{Methods}

A cross-sectional study was conducted in Medan in February and March 2011. Children aged 5 to 18 years who had household contact with an adult tuberculosis patient were included in this study. Uncooperative children as well as patients with an immunocompromised status (malnutrition, HIV infection, malignancy, morbilli, pertussis, varicella, and long-term immunosuppressant use) and history of atopy were excluded.

Subjects were divided into two groups, those exposed to passive smoke and those not exposed to passive smoke, with 70 children in each group. We recorded the baseline characteristics of subjects and the information obtained from questionnaires filled by parents. Tuberculin test was performed on all subjects, with $0.1 \mathrm{ml}$ of 2TU PPD RT 23 solution intradermally on the volar surface of the left forearm. The induration was measured after 48 to 72 hours. Tuberculin test was considered positive for induration diameter $\geq$ $10 \mathrm{~mm}$. We considered positive tuberculin skin tests to be indicative of TB infection.

This study was approved by the Research Ethics Committee of the Faculty of Medicine at the University of Sumatera Utara. Chi-square test was used to evaluate the relationship between passive smoking and M. tuberculosis infection, with SPSS software version 15.0. The significance level was accepted as $\mathrm{P}<0.05$.

\section{Results}

Of the 242 children who had household contact with adult pulmonary tuberculosis patients, 142 were eligible for the study. The children were divided into two groups: 72 children exposed to passive smoke and 70 not exposed to passive smoke. In the passive smoke group, two children were excluded because their tuberculin tests were not read within 48 to 72 hours after test administration. Hence, 140 children were included in the study, with 70 subjects per group.

Demographic characteristics were similar between the groups (Table 1). The mean ages were 9.2 years and 10.5 years in those exposed and not exposed to passive smoke, respectively. Mean weights were 26.4 $\mathrm{kg}$ and $32.4 \mathrm{~kg}$, and mean heights were $127.1 \mathrm{~cm}$ and $132.8 \mathrm{~cm}$, in those exposed and not exposed to passive smoke, respectively. The majority of subjects had good nutritional status. There were 4 children with obesity in the passive smoke group (5.7\%). Most children in both groups had received BCG immunizations.

The occurence of M. tuberculosis infection was significantly higher in those exposed to passive smoke than the unexposed group $(81.4 \%$ vs. $52.9 \%$, respectively) $(\mathrm{P}=0.0001$; Table 2$)$.

In the passive smoke group, there were associations between $M$. tuberculosis infection and the following: nutritional status $(\mathrm{P}=0.044)$, paternal education $(\mathrm{P}=0.022)$, and maternal education $(\mathrm{P}=0.038)$. However, there were no associations between $M$. tuberculosis infection and familial income $(\mathrm{P}=0.223)$ or $\mathrm{BCG}$ vaccination $(\mathrm{P}=0.910)$ (Table 3$)$.

\section{Discussion}

Tuberculosis and smoking are both significant public health problems. ${ }^{7}$ Chronic exposure to cigarette smoke may result in changes to the quantity and composition of the mucus layer, subsequently impairing mucociliary clearance of pathogens, changing the hydration state of the mucus, and promoting colonization in the airway lumen. ${ }^{10} \mathrm{We}$ found a significant association between exposure to passive smoke and prevalence of M. tuberculosis infection: of 70 children exposed to passive smoke, 57 children tested positively for M. tuberculosis infection $(\mathrm{P}=0.0001)$. These findings are consistent with a South African study of 1,344 children in which $1,170(87 \%)$ were passive smokers and more often had positive tuberculin tests (34\%; OR 1.89; $95 \%$ CI 1.24 - 2.86). ${ }^{7}$ Another study in Barcelona, 
Novaily Zuliartha et al: Passive smoking and M. tuberculosis infection

Table 1. Demographic characteristics of subjects

\begin{tabular}{|c|c|c|}
\hline Characteristics & $\begin{array}{l}\text { Exposed to passive smoke } \\
\qquad(\mathrm{n}=70)\end{array}$ & $\begin{array}{l}\text { Not exposed to passive smoke } \\
\qquad(\mathrm{n}=70)\end{array}$ \\
\hline Mean age, years (SD) & $9.2(3.08)$ & $10.5(1.22)$ \\
\hline \multicolumn{3}{|l|}{ Gender, n (\%) } \\
\hline Male & $33(47.1)$ & $29(41.4)$ \\
\hline Female & 37 (52.9) & $41(58.8)$ \\
\hline Mean body weight, kg (SD) & $26.4(9.92)$ & $32.4(13.10)$ \\
\hline Mean body height, cm (SD) & $127.1(17.20)$ & $132.8(20.24)$ \\
\hline Mean EID index, \% (SD) & $95.8(11.00)$ & $99.6(12.07)$ \\
\hline \multicolumn{3}{|l|}{ Nutritional status, $\mathrm{n}(\%)$} \\
\hline Severe malnutrition & 0 & 0 \\
\hline Moderate malnutrition & $23(32.9)$ & $16(22.9)$ \\
\hline Normoweight & $42(60.0)$ & $45(64.3)$ \\
\hline Overweight & $5(7.1)$ & $5(7.1)$ \\
\hline Obese & 0 & $4(5.7)$ \\
\hline \multicolumn{3}{|l|}{ Paternal education, $\mathrm{n}(\%)$} \\
\hline Elementary school & $7(10.0)$ & $9(12.9)$ \\
\hline Junior high school & $13(18.6)$ & $9(12.9)$ \\
\hline Senior high school & $38(54.3)$ & $47(67.1)$ \\
\hline Post high school & $12(17.1)$ & $5(7.1)$ \\
\hline \multicolumn{3}{|l|}{ Maternal education, n (\%) } \\
\hline Elementary school & $3(4.3)$ & $6(8.6)$ \\
\hline Junior high school & $22(31.4)$ & $16(22.9)$ \\
\hline Senior high school & $38(54.3)$ & $43(61.4)$ \\
\hline Post high school & $12(17.1)$ & $5(7.1)$ \\
\hline \multicolumn{3}{|l|}{ Monthly family income, n (\%) } \\
\hline$<1,000,000$ IDR & $16(22.9)$ & $13(18.6)$ \\
\hline $1,000,000-2,000,000$ IDR & $33(47.1)$ & $35(50.0)$ \\
\hline$>2,000,000$ IDR & $21(30.0)$ & $22(31.4)$ \\
\hline \multicolumn{3}{|l|}{ BCG vaccination, $\mathrm{n}(\%)$} \\
\hline Yes & $53(75.7)$ & $42(60.0)$ \\
\hline No & $17(24.3)$ & $28(40.0)$ \\
\hline
\end{tabular}

Table 2. Association between passive smoke and M. tuberculosis infection

\begin{tabular}{|c|c|c|c|c|}
\hline & \multicolumn{2}{|c|}{ M. tuberculosis infection } & \multirow{2}{*}{$\begin{array}{l}\text { Total } \\
\mathrm{n}(\%)\end{array}$} & \multirow[b]{2}{*}{$P$ value } \\
\hline & $\begin{array}{c}\text { Yes } \\
\text { n (\%) }\end{array}$ & $\begin{array}{c}\text { No } \\
\mathrm{n}(\%)\end{array}$ & & \\
\hline \multicolumn{5}{|c|}{ Passive smoking } \\
\hline Yes & 57 (81.4) & $13(18.6)$ & 70 (100) & 0.0001 \\
\hline No & $37(52.9)$ & $33(47.1)$ & $70(100)$ & \\
\hline Total & 94 & 46 & 140 & \\
\hline
\end{tabular}

aimed to assess the effect of passive smoking on the development of active pulmonary tuberculosis in children immediately following infection by $M$. tuberculosis within the family. Authors found that passive smoking in children was associated with an increased risk of developing pulmonary tuberculosis immediately following infection (OR 5.29; 95\% CI 2.33 - 12.82; $\mathrm{P}<0.00001) .{ }^{11}$

Malnutrition and tuberculosis are problems of considerable magnitude in most underdeveloped regions of the world. These two problems interact, with protein-energy malnutrition and micronutrient deficiency increasing the risk of tuberculosis. ${ }^{12}$ We also found a significant relationship between nutritional status and M. tuberculosis infection in passive smokers $(\mathrm{P}=0.044)$. Malnutrition is known to be associated with anergic tuberculin test results in internationally adopted children. However, a Minnesota study found that the tuberculin skin test induration response was not associated with nutritional status, and that in high a M. tuberculosis prevalence region, malnutrition presented a considerable risk for progression to 
Novaily Zuliartha et al: Passive smoking and M. tuberculosis infection

Table 3. Association demographics characteristics for M.tuberculosis infection in passive smoke group

\begin{tabular}{|c|c|c|c|c|}
\hline & \multicolumn{2}{|c|}{ M. tuberculosis infection } & \multirow[b]{2}{*}{$\begin{array}{l}\text { Total } \\
\text { n (\%) }\end{array}$} & \multirow[b]{2}{*}{$P$ value } \\
\hline & $\begin{array}{c}\text { Yes } \\
\text { n (\%) }\end{array}$ & $\begin{array}{c}\text { No } \\
\text { n (\%) }\end{array}$ & & \\
\hline \multicolumn{5}{|l|}{ Nutritional status, n (\%) } \\
\hline Moderate malnutrition & $20(35.1)$ & $3(23.1)$ & $23(32.9)$ & 0.044 \\
\hline Normoweight & $35(61.4)$ & $7(53.8)$ & $42(60.0)$ & \\
\hline Overweight & $2(3.5)$ & $3(23.1)$ & $5(7.1)$ & \\
\hline \multicolumn{5}{|l|}{ Paternal education, n (\%) } \\
\hline Primary school & $4(7.0)$ & $3(23.1)$ & $7(10.0)$ & 0.022 \\
\hline Junior high school & $12(21.1)$ & $1(7.7)$ & $13(18.6)$ & \\
\hline Senior high school & $34(59.6)$ & $4(30.8)$ & $38(54.3)$ & \\
\hline Post high school & $7(12.3)$ & $5(38.5)$ & $12(17.1)$ & \\
\hline \multicolumn{5}{|l|}{ Maternal education, n (\%) } \\
\hline Primary school & $2(3.5)$ & $1(7.7)$ & $3(4.3)$ & 0.038 \\
\hline Junior high school & $19(33.3)$ & $3(23.1)$ & $22(31.4)$ & \\
\hline Senior high school & $33(57.9)$ & 5 (38.5) & $38(54.3)$ & \\
\hline Post high school & $3(5.3)$ & $4(30.8)$ & $7(10.0)$ & \\
\hline \multicolumn{5}{|l|}{ Monthly family income, n (\%) } \\
\hline IDR $1,000,000$ & $15(26.3)$ & $1(7.7)$ & $16(22.9)$ & 0.223 \\
\hline IDR $1,000,000-2,000,000$ & $27(47.4)$ & $6(46.2)$ & $33(47.1)$ & \\
\hline$>$ IDR 2,000,000 & $15(26.3)$ & $6(46.2)$ & $21(30.0)$ & \\
\hline \multicolumn{5}{|l|}{ BCG vaccination, n (\%) } \\
\hline Yes & $43(75.4)$ & $10(76.9)$ & $53(75.7)$ & 0.910 \\
\hline No & $14(24.6)$ & $3(23.1)$ & $17(24.3)$ & \\
\hline
\end{tabular}

tuberculosis disease. ${ }^{13}$ In China, adult patients with obesity had a lower risk of active pulmonary tuberculosis. ${ }^{14}$ A Pakistani study to determine the frequency of known risk factors in confirmed cases of tuberculosis in children found that family education, especially maternal education, and BCG vaccination were the two most important factors in preventing tuberculosis in children. Malnutrition, measles and steroid therapy were also found to be risk factors for development of tuberculosis in children. ${ }^{15}$ However, a West Africa study found that nutritional status and presence of a BCG scar were not independent risk factors for positive tuberculin test results in children. ${ }^{18}$ A Jakarta study aimed to investigate the nutritional status of patients with active tuberculosis compared that of healthy controls revealed that compared to the control, tuberculosis patients had significantly lower body mass index, skinfold thickness, mid-upper arm circumference, proportion of fat, and concentrations of serum albumin, blood hemoglobin, plasma retinol and plasma zinc. ${ }^{17}$

We found that family income was not associated with M. tuberculosis infection in the passive smoking group, consistent with a South African study. ${ }^{7}$ Education is an important factor to determine the socio-economic status of a person and thus the ability to afford healthy environments and understanding of the disease. Parents with a higher education level are more likely to understand the importance of screening their children for TB. ${ }^{15}$ Similarly, we found significant associations between paternal $(\mathrm{P}=0.022)$ and maternal education levels $(\mathrm{P}=0.038)$ with $\mathrm{M}$. tuberculosis infection in the passive smoking group. A Greenland study also showed that maternal education was associated with the risk of M. tuberculosis infection in children. ${ }^{18}$

Children who received BCG vaccinations may have false positive reactions to tuberculin tests. ${ }^{19,20}$ However, we found no association between BCG vaccination and $M$. tuberculosis infection in the passive smoking group. Similarly, a West Africa study suggested that positive tuberculin tests in children probably reflect $M$. tuberculosis infection, regardless of their BCG vaccination status. ${ }^{16}$ A Nigerian study in apparently healthy children aged 3 to 59 months found that although tuberculin test positivity is 
usually attributed to M. tuberculosis infection, the effect of previous BCG vaccination, especially in children, should be taken into consideration when interpreting tuberculin test results. There was a significant difference in the overall prevalence of positive tuberculin tests $(\geq 10 \mathrm{~mm})$ between BCGvaccinated and unvaccinated in children $(\mathrm{P}=$ 0.0034). ${ }^{21}$ Furthermore, a Turkish study in children aged 1 to 6 years suggested that average tuberculin test induration in BCG-vaccinated children is significantly higher than that in unvaccinated children. ${ }^{19}$ However, a Brazilian study found that BCG vaccination-induced tuberculin reactivity was indistinguishable for results under $15 \mathrm{~mm}$. There was no evidence for BCG effect if positive results were defined as $\geq 15 \mathrm{~mm} .{ }^{22}$ A Peruvian study suggested that a BCG scar was a sensitive indicator of vaccination status for up to 3 years after vaccine administration in the first month of life. Although nearly a quarter of the children had a tuberculin response of $>5 \mathrm{~mm}$ six months after vaccination, tuberculin test results $>10 \mathrm{~mm}$ did not occur in the absence of exposure to a person with tuberculosis. ${ }^{23}$ A study in Southern Mexico found that tuberculin test results helped identify children in the BCG-vaccinated population who had recent exposure to pulmonary tuberculosis, were probably infected with M. tuberculosis, and could benefit from treatment for their latent tuberculosis infection. ${ }^{24}$ We considered our subjects to be TB-infected if their tuberculin reactivity was $\geq 10 \mathrm{~mm}$.

The limitation of this study was not evaluating the number of cigarettes smoked daily by active smokers in the house. Further study is needed to assess the level of exposure to cigarette smoke on the risk of M. tuberculosis infection. In conclusion, there is association between exposure to passive smoke and $\mathrm{M}$. tuberculosis infection in children with adult household tuberculosis contact.

\section{References}

1. Aditama TY, Kamso S, Basri C, Surya A, editors. Pedoman nasional penanggulangan tuberkulosis. $2^{\text {nd }}$ ed. Jakarta: Departemen Kesehatan Republik Indonesia; 2008.

2. Rahajoe NN, Basir D, MS Makmuri, Kartasasmita CB, editors. Pedoman nasional tuberkulosis anak. $2^{\text {nd }}$ ed. Jakarta: UKK Respirologi PP IDAI; 2007.
3. Varaine F, Henkens M, Grauzard V, editors. Tuberculosis. $5^{\text {th }}$ ed. Med Sans Frontieres. 2010.

4. Ahmed T, Sobhan F, Ahmed AMS, Banu S, Mahmoed AM, Hyder KA, et al. Childhood tuberculosis: a review of epidemiology, diagnosis and management. Infect Dis J Pakistan. 2008;17:52-60.

5. Menzies D, Schwartzman K, Pai M. Immune-based test for tuberculosis. In: Schaaf HS, Zumla AI, editors. Tuberculosis: a comprehensive clinical reference. Europe: Elsevier; 2009. p. 179-92.

6. Janson C. The effect of passive smoking on respiratory health in children and adults. Int J Tuberc Lung Dis. 2004;8:5106.

7. den Boon S, Verver S, Marais BJ, Enarson DA, Lombard CJ, Bateman ED, et al. Association between passive smoking and infection with mycobacterium tuberculosis in children. Pediatrics. 2007;119:734-9.

8. Zellweger JP. Tobacco and tuberculosis. Monaldi Arch Chest Dis. 2008;69:83-5.

9. Leung CC, Lam TH, Ho KS, Yew WW, Tam CM, Chan WM, et al. Passive smoking and tuberculosis. Arch Intern Med. 2010;170:287-92.

10. Glader P, Möller S, Lilja J, Wieslander E, Löfdahl CG, von Wachenfeldt K. Cigarette smoke extract modulates respiratory defence mechanisms through effects on T-cells and airway epithelial cells. Respir Med. 2006;100:818-27.

11. Altet MN, Alcaide J, Plans P, Taberner JL, Saltó E, Folguera, et al. Passive smoking and risk of pulmonary tuberculosis in children immediately following infection. A case-control study. Tuber Lung Disease. 1996;77:537-44.

12. Gupta KB, Gupta R, Atreja A, Verma M, Vishvkarma S. Tuberculosis and nutrition. Lung India. 2009;26:9-16.

13. Mandalakas AM, Kirchner HL, Iverson S, Chesney M, Spencer MJ, Sidler A, et al. Predictors of Mycobacterium tuberculosis infection in international adoptees. Pediatrics. 2007;120:e610-6.

14. Leung CC, Lam TH, Chan WM, Yew WW, Ho KS, Leung G, et al. Lower risk of tuberculosis in obesity. Arch Intern Med. 2007;167:1297-304.

15. Haq S, Hussain M, Krishin J, Abbasi S. Risk factors of tuberculosis in children. Ann Pak Inst Med Sci. 2010;6:504.

16. Leinhardt C, Sillah J, Fielding K, Donkor S, Manneh K, Warndorff $\mathrm{D}$, et al. Risk factors for tuberculosis infection in children in contact with infectious tuberculosis cases in the Gambia, West Africa. Pediatrics. 2003;111:e608-14.

17. Karyadi E, Schultink W, Nelwan RH, Gross R, Amin Z, Dolmans WM, et al. Poor micronutrient status of active 
Novaily Zuliartha et al: Passive smoking and M. tuberculosis infection

pulmonary tuberculosis patients in Indonesia. J Nutr. 2000;130:2953-8.

18. Søborg B, Andersen AB, Melbye M, Wohlfahrt J, Andersson M, Biggar RJ, et al. Risk factors for Mycobacterium tuberculosis infection among children in Greenland. Bull World Health Organ. 2011;89:741-8.

19. Besser RE, Pakiz B, Schulte JM, Alvarado S, Zell ER, Kenyon $\mathrm{TA}$, et al. Risk factors for positive mantoux tuberculin skin tests in children in San Diego, California: evidence for boosting and possible foodborne transmission. Pediatrics. 2001;108:305-10.

20. Bozaykut A, Ipek IO, Ozkars MY, Seren LP, Atay E, Atay Z. Effect of BCG vaccine on tuberculin skin test in 1-6-year-old children. Arch Paediatr. 2002;91:235-8.

21. Mustapha MG, Garba AM, Rabasa AI, Gimba MS. Prevalence of mantoux test positivity among apparently healthy children in Maiduguri, Nigeria. South African J Child Health. 2009;3:80-2.

22. Bierrenbach AL, Cunha SS, Barreto ML, Pereira SM, Dourado I, Ichihara MY, et al. Tuberculin reactivity in a population of schoolchildren with high BCG vaccination coverage. Rev Panam Salud Publica. 2003;13:285-93.

23. Santiago EM, Lawson E, Gillenwater K, Kalangi S, Lescanao AG, Du Quella G, et al. A prospective study of bacillus Calmette-Guerin scar formation and tuberculin skin test reactivity in infants in Lima, Peru. Pediatrics. 2003;112:e298.

24. Garcia-Sancho FMC, Garcia-Garcia L, Jimenez-Corona ME, Palacios-Martinez M, Ferreyra-Reyes LD, Canizales-Quintero $\mathrm{S}$, et al. Is tuberculin skin testing useful to diagnose latent tuberculosis in BCG-vaccinated children? Int J Epidemiol. 2006;35:1447-54. 